\title{
REPRESENTING INCLUSION OF PEOPLE WITH DISABILITIES: ANALYSING DISCOURSES IN A MIXED-METHODS STUDY
}

\author{
Mari Kivistö \\ University of Lapland
}

\begin{abstract}
This study discusses discursive representations of the inclusion of people with disabilities. Analysing discourses was conducted in the third phase of the author's mixed-methods study. The study participants lived in a municipality in Northern Finland and were receiving personal assistance services for persons with disabilities. In the analysis results, the participants did not discuss inclusion in their everyday life using formal inclusion-related concepts. Neither did social workers when writing about the participants in their service plans. The findings illustrate how the everyday discourses usually present the inclusion of people with disabilities through and after first representing their exclusion. Representing inclusion of people with disabilities is vague, however dynamic, as representing could eventually lead to the inclusion in the use of language.

KEYWORDS: disability, discourse, inclusion, mixed methods, participation, people with disabilities.
\end{abstract}

\begin{abstract}
Anotacija
Straipsnyje analizuojama asmenų, turinčių negalę, socialinès ịtraukties diskursyvinè reprezentacija. Diskursų analizė atlikta trečioje mišrių metodų tyrimo stadijoje. Tyrimo dalyviai gyvena Šiaurès Suomijos savivaldybeje, jiems teikiama asmeninio asistento paslauga, kaip turintiesiems negalią. Kaip rodo analizès rezultatai, informantai neaptarinėjo savo socialinès ịtraukties ị kasdienị gyvenimą vartodami formalius, su ịtrauktimi susijusius terminus. Šių terminų nevartojo ir socialiniai darbuotojai, rengdami paslaugų klientams planus. Tyrimo rezultatai atskleidžia, kad paprastai asmenų, turinčių negalę, ịtrauktị atskleidžia kasdienès kalbos diskursai, prieš tai reprezentavę jų atskirtị. Asmenų su negale ịtraukties reprezentacija yra miglota, tačiau dinamiška, vèliau galinti paskatinti jų ịtrauktị per kalbą.

PAGRINDINIAI ŽODŽIAI: negalè, diskursas, ịtrauktis, mišrūs metodai, dalyvavimas, asmuo negalès situacijoje.
\end{abstract}

\section{Introduction}

The main goals of contemporary disability politics are the inclusion and participation of people with disabilities. The most important of these policies is the United Nations Convention on the Rights of Persons with Disabilities (UNCRPD) (Grue, 2009; Roulstone, 2013). The main principles of the convention (Article 3) are respect for individual autonomy, including the freedom to make one's own choices; full, effective participation and inclusion in society; equity of opportunity; and accessibility. The Finnish government signed both the UNCRPD and its optional protocol in 2007 but did not ratify the convention until 10 June 2016. Before 
ratification, the Finnish government undertook several legal reforms to promote the self-determination of people with disabilities.

In Finland, as in many other Western countries, rights-based disability policies, legislation and services have been strengthened progressively (e.g. Miettinen and Teittinen, 2014). However, this development has encountered economic problems, including limited resources and funding. Many municipalities have struggled to meet their legal responsibilities to offer services, leading to sharpening inequalities, welfare state cutbacks, a results orientation and decentralisation (Miettinen and Teittinen, 2014). In the context of this research, the municipality in Northern Finland where the study participants received personal assistance services was quite economically stable until recent years when it faced major economic difficulties, especially related to unemployment.

The current economic situation in Finland has spurred many structural changes to the organisation of health and social services, including the integration and digitisation of services as widely as possible and, most importantly, modifications of the entire structures of offering services. Under regional government reform, the responsibility for running health and social services will be transferred from municipalities to 18 counties in early 2019. One goal cited for this centralisation is narrowing the inequalities between citizens. In this context, it is crucial to take into account the research-based evidence on the inclusion and participation of people with disabilities.

The overall purpose of this paper is to discuss the image of the fulfilment of the inclusion and participation of people with disabilities in Finland. Discourses of inclusion are analysed through the representations of the four disabled participants and their social workers, who were responsible for client documentation in social work practices. Discourse analysis was conducted as the third part of this mixed-methods study. This explicit mixed-methods design served as a useful tool for studying multiple images of both inclusion (and participation) and disability and made it possible to draw some unanimous conclusions. The mixed-methods approach and the sequential integration of quantitative and qualitative data were adopted to generate a greater understanding of this complex phenomenon. This paper specifically focusses on analysing discourses in the mixed-methods context. The research questions addressed are as follows:

- How do people with disabilities represent their inclusion when referring their every-day life?

- What kinds of discourses on the inclusion of people with disabilities are represented in service plans written by social workers?

The contexts of these discourses and the possible intentions and impacts of talking and writing in these specific manners used are also discussed. 
The article is organised as follows. First, the methodological context of the study is presented and justified. The concepts of inclusion, participation and disability are discussed, and then the data and study method are presented. Discourse analysis is applied to explore and represent the ways people with disabilities talk and social workers write about the inclusion of (for) people with disabilities. In the conclusion, both the content (image) of discursive inclusion and the methodology of the study are discussed.

\section{Concepts of inclusion, participation and disability}

The concept of inclusion is difficult to explicitly define and can even be considered to be somewhat unclear. In general, though, inclusion indicates a kind of attitude that should be present in all arenas and activities of society to achieve the goal of an ethically and socially sustainable society. Inclusion refers, on one hand, to the individual experience of feeling included and engaged but, on the other hand, also to the experience of relational belonging, for example, in one's family, community or society. Inclusion can also be conceptualised by referring to other notions such as empowerment, engagement, life politics, participation, client-centredness, social capital, knowledge and agency (e.g. Kivistö, 2014). The discourse of inclusion is both intentional and political (Solvang, 2000; Miettinen, and Teittinen, 2014). These diverse conceptual foundations point to the necessity to study the discourses of inclusion.

Finnish legislation explicitly promotes but does not clearly define citizens' participation. However, problems have been identified in the wellbeing, living conditions and participation of people with disabilities (e.g. Haarni, 2006). According to recent Finnish research, the participation of people with severe disabilities especially needs greater attention (Järvikoski et al., 2015). In research based on interviews of people with disabilities, Hammel et al. (2008) concluded that participation is individual but also entails various shared values, such as respect and dignity, as well as rights and responsibilities. Participation encompasses choice, control, meaningful engagement, access, opportunity and achievement of impacts, among other components (Hammel et al., 2008)

Even when participation and other inclusion-related concepts are valued positively, the perspectives of these notions are critical. In the present study, the concept of participation primarily entails action, in other words, participating. Participation is considered to be part of the broader concept of inclusion. However, neither is inclusion considered to be a self-explanatory concept. Instead, inclusion can be viewed as a political phenomenon in which those with power use a top-down approach to define what other people who lack power need, should do or be in- 
cluded in (see also Solvang, 2000; Helne, 2002). As stated, the main principles of the UNCRPD are respect for individual autonomy and freedom to make one's own choices; full, effective participation and inclusion; equity of opportunity; and accessibility. This means that people with disabilities should have all the equal opportunities to make their own choices on their participation and inclusion; where they want to participate and to be included in.

The concept of disability is similarly complex, contextual and political (e.g. Grue, 2009; 2011b). Debates on discourses and representation of disability have occupied a central place in the disability field (Grue, 2009, p. 306), and the UNCRPD describes disability as an evolving concept (Grue, 2009; Griffo, 2014). During modernisation, disability was presumed to be a condition defined through medical concepts, and the medical model of disability remains visible in politics, services and rehabilitation (e.g. Grue, 2009; Røberg et al., 2016). However, many disability researchers have attempted to resist the medical approach for decades (e.g. Solvang, 2000). The historical emergence of the social model of disability promoting the inclusion and participation of people with disabilities (Oliver, 1990; 1996) was related to the rise of other radical movements. The social model of disability (Oliver, 1990; 1996; 2013) defines disability as the result of societal oppression of people considered to be disabled (e.g. Grue, 2009). This model emphasises disabling processes and the meaning of disabling structures, represents disability as a collective expression of social oppression and highlights society's responsibilities for person's condition of disability (Griffo, 2014; Vehmas and Watson, 2014). Disability can even be defined as a discursive and political construction of the welfare state which serves the state's need to decide and distinguish who is and is not qualified for services (Solvang, 2000). Although the social model of disability has also been criticised, its main goal, as Oliver (2013) highlights, has always been to improve the lives of people with disabilities, and it has accomplished this.

Contemporary Nordic social research on disability has viewed disability as a result of the interactive relationship between the individual and society/structures (Shakespeare, 2004). This relational model has been developed largely in support of the strong welfare state (Grue, 2009, p. 314; 2011b, p. 11). Finnish disability politics explicitly promote equality, participation and the needed support and services for people with disabilities. Saloviita (2013) identifies the support paradigm as a contemporary Finnish disability paradigm, although it sometimes seems that discourses have changed more than practices (Saloviita, 2013).

In addition to these different models of disability, the concept of disability is complex due to the various identities held by individuals in this heterogeneous group. Disability should not be considered as all-inclusive label (Stamou et al., 2016). Unfortunately, in Finland, even political decision makers and legislators 
have considered people with disabilities to be a homogenous population (Hästbacka and Konttinen, 2012). Representing people with disabilities as a single group risks their inclusion as individuals. When promoting the self-determination, empowerment and agency of people with disabilities, it is necessary to also ensure that the needed services are available (Røberg et al., 2016, p. 11).

\section{The mixed-methods context}

The research discussed in this article was conducted as the last (third) part of a sequential mixed-methods study (sub-studies I-III) addressing the participation and inclusion of people with disabilities in one locality in Northern Finland. The municipality gave permission for conducting the research, and the individual participants gave informed consent. Participation was voluntary and based on detailed information shared by researcher.

Finnish disability researchers (e.g. Martin, 2016) have sometimes used both quantitative and qualitative data in their studies, but generally, explicit mixed-methods research (e.g. Tashakkori and Teddlie, 2003; Creswell and Plano Clark, 2011) has been rare. Integrating different methodological approaches, however, enables capturing both the diversity and the comprehensiveness of the phenomenon observed. According to Ronkainen (1999), various research methodologies and methods can be seen as different ways of knowing that are not mutual exclusive. Mixedmethods research consists of a meaningfully combination of quantitative and qualitative methodologies. In a sequential mixed-methods study, quantitative and qualitative data are sequentially and thoughtfully gathered in such a way that one type of data explains and completes the other (Creswell and Plano Clark, 2011). In the present mixed-methods study, three sub-studies covered a continuum from the macro- to the micro-level. The first sub-study, which applied a quantitative research approach, elaborated the functional participation of people with disabilities. The qualitative second sub-study was conducted to elucidate the experiences of people with disabilities in participation and inclusion. In the third sub-study, which is the main focus of this paper, elements of discourse analysis were applied to interpret the inclusion of people with disabilities as represented in the language used by people with disabilities themselves in interviews and by social authorities in written service plans.

The data analysed in the quantitative study (sub-study I) were gathered from the municipality's personal assistance client register $(N=234)$ from 2009. Another set of material (sub-study II) was gathered between 2010 and 2013 by conducting one or two interviews (11 total) with eight participants receiving personal assistance in the locality. Later, the researcher selected the interviews and service plans of 
four participants for further analysis (sub-study III). In the sequential mixed-methods approach, the criteria for selecting data and participants for the subsequent sub-study were systematically determined based on the analysis and findings of the previous sub-study. This procedure is called sample integrating in mixed-methods research and is employed to enhance the validity of a study (e.g. Creswell and Plano Clark, 2011).

The aims of Finnish disability policy are to support the working and functional capacity of people with disabilities and to promote their individual autonomy. However, the analysis of the quantitative data (sub-study I) showed that the participants $(N=234)$ were virtually excluded from some areas of life despite inclusive politics and the receipt of personal assistance services intended to facilitate their participation. Less than $4 \%$ of the participants were engaged in paid work, and according to the client register data, only another 3\% participated in arranged work activities, such as supported or sheltered work. Participants, especially younger ones, exhibited higher participation levels in education, arranged daily activities, organisational activities and hobbies. Considering the goals of full participation by people with disabilities, the participants' participation was unevenly distributed, and nonparticipation was cumulative (see also Järvikoski et al., 2015).

After the quantitative study, the research process was continued with a qualitative study (sub-study II). Two participants from each of four clusters based on the cluster analysis conducted in sub-study I were invited to participate. The clusters and the participants differed by, for example, participation rates. The qualitative sub-study, in which interviews and qualitative content analysis were conducted, highlighted multiple barriers to the participation and inclusion of people with disabilities caused by inequality, environmental and attitudinal obstacles, inadequate service or service quality and problematic encounters with social and healthcare authorities. Most participants, to some extent, had also experienced disability as an obstacle to their participation and inclusion. Several participants reported childhood experiences that influenced their inclusion as adults. The participants' experiences related to opportunities to make their own choices were mixed.

The qualitative sub-study II explained and expanded the results of quantitative sub-study I. However, the integrated findings were also mixed as some participants in the statistic-based cluster characterised by a high participation rate in sub-study I reported several experiences of exclusion in qualitative sub-study II. As well, some participants who did not actively participate according the data in sub-study I reported feeling included and engaged in sub-study II. This discrepancy points to both the dynamics of inclusion and the impact of the methodological context. In a typical sequential mixed-methods design, the research process would end after sequentially gathering, analysing and interpreting of both quantitative and qualita- 
tive data (sub-studies I and II). However, in this research, the results of these two sub-studies were interpreted through the already-familiar discourses researchers, politicians and disability activists have used for years to discuss, for example, participation, accessibility, services and equality. In an attempt to identify the words and discourses used concerning inclusion in the everyday life of people with disabilities, the research process was continued by applying elements of the discourse study method (sub-study III). As Grue (2011b, p.10) argued, 'disability is so complex as a concept that it cannot be properly understood without reference to complex mechanisms of discourse'. Overall, a need for more discursive research on disability has been identified (e.g. Grue, 2009).

\section{Data and participants of the discursive sub-study}

The data analysed in the discursive sub-study were collected during the mixedmethods study. Four interviews $(N=4)$ and their service plans were selected for analysis by applying elements of discourse analysis. All the interviewees, with an age range of 25-60 years, had motor-skills impairments and used walkers or wheelchairs. Two participants were female, and two were male. Three of the four had had disabilities from birth. The length of the tape-recorded interviews varied from 1 hour to nearly 3 hours. Regarding the data from the four interviewees' service plans, making service plans is a statutory duty in Finnish social services. The legislation also states that the clients' opinions and the views must be documented in the plan. Three individual social workers wrote the service plans analysed, and one participant had two service plans, so the data analysed came from five service plans. The longest service-plan was around six pages.

\section{Method and analysis}

Solvang (2000) argued that the changing social position of people with disabilities can be effectively measured through the changing importance of various discourses. Solvang's (2000; see also Grue, 2011b; 2011a) main conclusion is that disability theories can be developed through analysing discourses. The central hypothesis of discourse analysis is that language shapes and is shaped by social structures, interactions and roles (Grue, 2011b, p. 17). Critical discourse analysis $(\mathrm{CDA})$ is intended to make visible the relationship between language use and structures (e.g. Fairclough, 2012). Fairclough (2003, p. 2) explains that "language is dialectically interconnected with other elements of social life, so that social analysis and research always has to take account of language". In a CDA study on implementation of the UNCRPD, Liasidou (2014) showed how reality is built 
through the use of language and, conversely, how CDA can reveal these realitybuilding processes in language use.

In the present study, discourse analysis is considered to be a method to explore typical and meaningful ways of speaking, writing and producing social texts (e.g. Alvesson and Sköldberg, 2000; Fairclough, 2003). Communication and interaction produce shared meanings through discourses (Sunderland et al., 2009). Generally, discourses define what is viewed as meaningful and establish rules for ways of thinking (Solvang, 2000). Discourses are intentional and dynamic and capable of both changing and being changed (Fairclough, 2003; 2012). Instead of referring to particular discourse analysis methods, the author prefers to speak more openly of analysing discourses in this paper.

The two data types were analysed separately, but the same analytical process was applied to both the interview data and the service plan data. After several readings of the material, the researcher focussed on the vocabulary used in the data and sought to identify the words and representations that the participants used when referring to inclusion or constructing it in language use. The interviewees, for example, discussed inclusion and participation as the possibility to take an active role, make one's own decisions and participate in different areas of life (see also Järvikoski et al., 2015, p. 243). The service plan form used in this particular municipality asked social workers to assess and document their clients' participation in work, study and other activities and document their views. The analysis also evaluated the contexts in which inclusion was represented and considered the possible intentions of making these particular representations. In addition to typical ways of talking and writing on inclusion, possible exceptions were noted. The findings and identified discourses are described in more detail in the next section.

\section{Findings}

5.1. Representing and (re)constructing inclusion in the interviews

The participants constructed representations of inclusion in their everyday life and experiences. As Berger and Luckman (1995 [1966]) pointed out, language use originates in and refers to daily life. The participants did not usually refer to inclusion using the formal inclusion-related concepts of official disability politics. In the data, the participants instead talked about empowering fighting, being bra$v e$ and being able to adapt. Moreover, before raising their own inclusion-related representations, they often first represented exclusion. For example, they talked about a need to battle, need to disclose and being forced to give up. Representation 
usually started with negative aspects, although one participant's representation was an exception to this trend.

Fairclough (2013, p. 160) highlighted the distinction between the personal and social aspects of identity. Reinikainen (2007, p. 45) pointed out that the concept of subject refers to the object of language use influenced by hegemonic discourses, while identity refers to person's own views of their selves. In this study, three of the four interviewees generally represented themselves from negative positions, especially when they first started talking in the data. The participants described, for example, how they had been forced by someone (other people) or something (a community or society) to adopt particular negative subjective positions (e.g. beggar, explainer). These representations are related to the social model and social discourse of disability. One participant, a man in his early 40s, stated that he gave in several times when doing business with social and healthcare officials: "It is quite a hard struggle. (...) I was not able to fight anymore (...) so I gave in, let it be. I always had to explain my reasons and needs over and over again'. An interviewee in her 60s also often took the position of an excluded subject: 'I have adapted as I had to adapt as I did not get any other help. (...) I thought that I just had to settle for these." The medical and individualistic discourses of disability were also visible in the data. For example, a younger female participant explicitly referred to how "her impairment limits" her participation.

In contrast to the representations of exclusion and out-shutting positions, the participants referred to inclusion on a daily basis by representing their identities as being brave, gutsy, active, critical, a fighter, strong, adaptable and successful. The participants used this positive vocabulary when they represented their self without influence of others. This inclusive identity building usually became apparent in their use of language only as a counter-discourse after excluding positioning talk. However, in understanding language use as social process, the participants also empowered themselves by starting with the negatives but often ending with the positives in the episodes in the interview data. For example, after first describing disappointment related to seek an access to labour market, one participant eventually represented himself as a determined agent: "If I decide that I will find a place [a job], I'll find it! ... I always eventually do as I have decided."

One participant, a middle-aged man, was an exception as from the beginning of the interview, he represented himself as active, positive and brave, without starting with negatives:

I can go outside any time, by taxi or by wheelchair. (...) I am brave.

(...) I have always thought about everything in a positive way.

The inclusion-related representations in the interview data had three main contexts: individual, societal and social. As mentioned, representations in the indi- 
vidual context involved various discursive approaches to talking about the self, including both positive identities and negative subject positions. The societal context included references to, for example, environmental factors, services and society. The younger female participant, for instance, credited disability services for helping her achieve inclusion, but she represented inclusion in language use similarly to persons without disabilities:

It [services] enables us [people with disabilities] to participate in society and to feel engaged to society and to feel included in some groups of people and, most of all, in some groups of not only disabled people.

The social context related to representations of receiving support from other people, such as parents, other relatives, friends and those working in disability services, including taxi drivers, personal assistants and therapists. The younger female participant stated that her "current personal assistant is actually the very first person who has been able to get me to enjoy life". She represented herself as dependent when asking for help from her parents: "it was, for me personally, a terribly burdensome factor and still is." The older female participant also negatively perceived asking her son for help: "he is not my assistant". In contrast, the male participants positively represented receiving support also from their parents. Overall, the four participants quite often represented their encounters with social and health care officials and educators as excluding. One participant even found some encounters with particular peers from disability organisations to be excluding: "They are not interested. (...) They get help for themselves, but if someone else asks for help, they do not have advice on how to get any."

\subsection{Highlighting disability and justification of services in service plans}

In the service plan data, the social workers usually described the clients' disability-related difficulties and inabilities before their abilities, as in the participants' representations in the interview data. It seems that the inclusion of and for people with disabilities gains it meaning through first representing their exclusion. Regarding the service plan - data and the analysis of it, similar to the lack of use of the formal concept of inclusion among the interviewees with disabilities themselves, the social workers neglected this concept in their writing. Overall, the clients' resources, abilities and wishes related to services were rarely represented in these service plans. However, the writing by one of the three social workers was an exception.

As official documents, service plans should be considered to be products of intentional language use. However, the creation of genuinely client-driven servi- 
ce plans is still underway in social work practices in Finland. The service plans associated with the four selected interviewees (participants) assessed in the present study present three main discourses: client discourse, disability discourse and participation discourse. Client discourse refers to the typical ways of representing and assigning positions to the participants in the service plans. The social workers described their clients as objects more often than as active subjects. The clients' agency, especially as consumers, was not visible in these plans. In the vocabulary used, the plans referred to participants to as 'clients' or 'person' rather than by name, making the plans professional but distant.

Although social workers are qualified professionals who have special expertise in social wellbeing, the accounts social workers wrote in these service plans reflected the disability discourse and the medical model of disability. The social workers primarily wrote about their clients' severe disabilities, inabilities and difficulties in everyday life. These representations of the participants' exclusion due to their disabilities also reflected the need to justify providing services to the clients. Social workers justify their acts through documentation, and the medical model of disability seems to be useful for this purpose. Grue $(2009$, p. 314) argued that, in a welfare state, a medical diagnosis is the basis of access to economic benefits, technical assistance and other support or services that can affect everyday life. For example, in the younger female participant's service plan, the social worker justified and externalised her decision to give more personal assistance service by citing a doctor's medical account: "According to a doctor's statement, the amount of personal assistance service provided should be..." The social worker also stated that the future circumstances of the client's situation "will be checked at the hospital".

Another service plan of a one of the two male participant did not include any of his documented hopes or wishes. Instead, the social worker wrote, for example, that "the client had very difficult-staged tetraplegia". This statement highlights the disability instead of the person and represents medical-based naming to segregate people when offering disability services (see also Stamou et al., 2016, p. 9). Although this service plan represented some abilities, it first emphasised disabilities. Along with the medical model of disability, this type of representation can be seen as related to a normalisation discourse of disability (e.g. Solvang, 2000; Miettinen and Teittinen, 2014), highlighting the otherness of the person with disabilities. This discourse is contradictory to the UNCRPD, which specifically stresses the capabilities of people with disabilities, in addition to inclusion and participation.

Current disability law also strongly affects social authorities' writings (see Saloviita, 2013). The Disability Services Act in Finland stresses the severity of disabilities needed to receive personal assistance services. The social workers likely 
attributed marginal subject positions to their clients with the aim of promoting their needs and justifying the personal assistance and other disability services needed. At the same time, the social workers justified their own decisions and actions as social authorities. As Liasidou (2014) showed, disability documents represent marginal subject positions for people with disabilities due to the need to promote equality for people with disabilities. According to Grue (2009, p. 317), "despite the development on social model discourse, there is always a need to establish some way of distinguishing the disabled population from the able-bodies".

In the few representations of inclusion in the service plans, the social workers mostly wrote about their clients' functional participation, primarily in leisure-time activities (participation discourse). The three of the four participants were born between 1960s - 1980s. However, the social workers did not document much of their clients' work or educational histories and even less so their future plans in these areas of life. This neglect violates not only the UNCRPD but also the aims of Finnish policymakers, who wish to see paid work and wages become the main income source for all those of working age and for disability to not be an automatic obstacle to employment (Hästbacka and Nygård, 2012). In these service plans, the social workers described the daily activities in which their clients engaged. Positively, these representations of functional participation might also have served as justification for support services for clients with disabilities. The activities of the other male participant were represented as follows:

The client goes to the movies; he listens to music and watches DVDs. He goes to the summerhouse with his parents. He participates in joint events in [the service house] and generally spends a lot of time outside his home.

However, sometimes, the functional participation of the participants was represented vaguely as, for example, more of a wish than a real act involving resources and support needed.

\section{Discussion}

The main principles of the UNCRPD include full, effective participation and inclusion in society. The findings of the present study, though, revealed that participants with disabilities did not use official and political concepts of inclusion and participation in discussing their daily life, even when challenged to do so in the interviews. Instead, they used representations such as (empowering) fighting and being brave when representing and constructing inclusion in their language use. This result is related to the observation that the words and concepts used by people with disabilities themselves are often significantly different from political discour- 
ses (Sunderland et al., 2009). The data even seem to indicate a discursive gap between official and everyday discourses (see also Reinikainen, 2007). Another finding was that most participants referred to inclusion using their own vocabulary only after first referring to exclusion. This finding also relates to language use as an empowering process as representing could eventually lead to the representations of inclusion in the use of language despite starting from the negatives.

According to the service plans data, even the social workers who were specialised in disability services and should be familiar with the contemporary rightsbased disability politics did not use the formal concepts of inclusion or participation. In the service plans, the social workers mostly addressed the inclusion of participants with disabilities by first highlighting their disabilities and then vaguely describing a few of their wishes, resources or activities. According to Sunderland et al. (2009), disability documents often begin with the assumption of the negative position of people with disabilities and then subsequently attempt to raise them to positions of equality. However, based on the data, there remains a need to promote the socio-political discourse in disability social-work practices against the hegemonic medical discourse. Overall, the medical and the social discourses of disability were identified in both sets of data. However, these discourses acted dynamic. As Grue (2009) argued, these discourses are not necessarily conflicting or exclusive but can be interactive and negotiating.

The limitations of the study arise from the small samples for both the interviewees and the service plans. However, the sequential mixed-methods context of the study increases validity, for example, through sequential data collection. The study data were collected from one locality in Finland, so the findings are not representative or generalisable. Deeper analysis of greater volumes of data should be carried out in future. However, the discursive findings of the present study are clearly important when discussing the implementation of full and effective inclusion and participation of people with disabilities. The ratification of the UNCRPD and the current attention on client participation are hopefully like to drive improvements in this area and in the current operation of health and social services in Finland.

The overall aim of the mixed-methods study design was to capture a picture of the inclusion of people with disabilities by applying and integrating different ways of knowing (see Ronkainen, 1999). From the meta-inferences and integrated conclusions, the image of inclusion formed by this mixed-methods study is both multiple and united. The image of inclusion varies depending on the chosen methodology, data and context (multiple images), but every methodology points out that the inclusion of people with disabilities was still unfilled (united image). The aim of analysing discourses in the third phrase of the mixed-methods study (sub-study III) was to identify the everyday discourses and representations of the 
inclusion and participation of (and for) people with disabilities through their own language use in interviews and through the texts of their service plans written by social workers. According to Grue $(2009$, p. 306; 2011a), there is a general need for research on disability-related discourses and, moreover, a recognised need for research on the types of discourses used in the disability field.

In conclusion, the discursive analysis reinforces the vague overall image of the inclusion of people with disabilities. However, by identifying particular everyday discourses, this analysis also diversifies the image of the inclusion of people with disabilities. The inclusion of people with disabilities can be assessed through analysing plural discourses to develop both theories and disability service practices. Multiple methodology is also recommended because of the diverse phenomenon. The interpretations of these findings can serve to enhance the inclusion of people with disabilities.

Received 20160912

Approved for publishing 20161203

\section{References}

Berger, L. P., Luckman, T. (1995 [1966]). Todellisuuden sosiaalinen rakentuminen. Tiedonsosiologinen tutkielma. Helsinki: Gaudeamus.

Creswell, J., Plano Clark, V. L. (2011). Designing and Conducting Mixed Methods Research. $2^{\text {nd }}$ edition. Thousand Oaks, CA: Sage.

Disability Services Act 1987/380. http://www.finlex.fi/fi/laki/ajantasa/1987/19870380 [Accessed: 04-01-2017].

Fairclough, N. (2003). Analysing Discourse: Textual Analysis for Social Research. London: Routledge.

Fairclough, N. (2012). Critical Discourse Analysis. The Critical Study of Language. $2^{\text {nd }}$ edition. London: Routledge.

Griffo, G. (2014). Models of Disability, Ideas of Justice, and the Challenge of Full Participation. Modern Italy, Vol. 19 (2), p. 147-159.

Grue, J. (2009). Critical Discourse Analysis, Topoi and Mystification: Disability Policy Documents from Norwegian NGO. Discourse Studies, Vol. 11 (3), p. 305-328.

Grue, J. (2011a). Discourse Analysis and Disability: Some Topics and Issues. Discourse and Society, Vol. 22 (5), p. $532-546$.

Grue, J. (2011b). Interdependent Discourses of Disability. A Critical Analysis of the Social/Medical Model Dichotomy. Norway: Faculty of Humanities, University of Oslo. https://www.duo.uio.no/bitstream/ handle/10852/26291/dravhandling-grue.pdf?sequence=2\&origin=publication_detail [Accessed: 04-012017].

Haarni, I. (2006). Keskeneräistä yhdenvertaisuutta. Vammaisten ihmisten hyvinvointi ja elinolot Suomessa tutkimuksen valossa. Raportteja 6/2006. Helsinki, Finland: Stakes.

Hammel, J., Magasi, S., Heineman A., Whiteneck G., Bogner J., Rodriquez, E. (2008). What does participation means? An insider's perspective from people with disabilities. Disability \& Rehabilitation, Vol. 30 (19), p. $1445-1460$.

Hästbacka, E., Nygård, M. (2012). Disability and Citizenship. Politicians’ Views on Disabled Person’s Citizenship in Finland. Scandinavian Journal of Disability Research, Vol. 15 (2), p. 125-142.

Helne, T. (2002). Syrjäytymisen yhteiskunta. Tutkimuksia 123. Helsinki, Finland: Stakes.

Järvikoski, A., Puumalainen, J., Härkäpää, K. (2015). Client Participation in Medical Rehabilitation for Adults with Severe Disabilities. Scandinavian Journal of Disability Research, Vol. 17 (3), p. 240-257.

Kivistö, M. (2014). Kolme ja yksi kuvaa osallisuuteen. Monimenetelmällinen tutkimus vaikeavammaisten ihmisten osallisuudesta. Rovaniemi, Finland: University of Lapland. 
Liasidou, A. (2014). Disabling Discourses and Human Rights Law: A Case Study Based on the Implementation of the UN Convention on the Rights of People with Disabilities. Discourse: Studies in the Cultural Politics of Education, Vol. 37 (1), p. 149-162.

Martin, M. (2016). Nuoruus, vammaisuus ja kuntoutuksen merkitys. Rovaniemi, Finland: University of Lapland.

Miettinen, S., Teittinen, A. (2014). Deinstitutionalisation of People with Intellectual Disabilities in Finland: A Political Perspective. Scandinavian Journal of Disability Research, Vol. 16 (1), p. 59-76.

Oliver, M. (1990). The Politics of Disablement. New York: St. Martin's Press.

Oliver, M. (1996). Understanding Disability. From Theory to Practice. Basingstoke: Palgrave.

Oliver, M. (2013). The Social Model of Disability: Thirty Years on. Disability and Society, Vol. 28 (7), p. 1024 1026.

Reinikainen, M. R. (2007). Vammaisuuden sukupuolittuneet ja sortavat diskurssit. Yhteiskunnallis-diskursiivinen näkökulma vammaisuuteen. Jyväskylä, Finland: Jyväskylän Yliopisto.

Røberg, A. S., Feiring, M., Romsland, G. I. (2016). Norwegian Rehabilitation Policies and the Coordination Reform's Effect: A Critical Discourse Analysis. Scandinavian Journal of Disability Research, Vol. 19 (1), p. $1-13$.

Ronkainen, S. (1999). Ajan ja paikan merkitsemät. Subjektiviteetti, tieto ja toimijuus. Helsinki, Finland: Gaudeamus.

Roulstone, A. (2013). Disability Research in the Nordic Context - Progress and Challenges in Investment Welfare States 1970-2013. Scandinavian Journal of Disability Research, Vol. 15 (1), p. 1-12.

Saloviita, T. (2013). Lines of Development in Social Research on Disability in Finland between the Years 19702010. Scandinavian Journal of Disability Research, Vol. 15, p. 38-54.

Shakespeare, T. (2004). Social Models of Disability and Other Life Strategies. Scandinavian Journal of Disability Research, Vol. 6 (1), p. 8-21.

Solvang, P. (2000). The Emergence of Us and Them Discourse in Disability Theory. Scandinavian Journal of Disability Research, Vol. 2 (1), p. 3-20.

Stamou, A. G., Alevriadou, A. Soufla, F. (2016). Representations of Disability from the Perspective of People with Disabilities and Their Families: A Critical Discourse Analysis of Disability Groups on Facebook. Scandinavian Journal of Disability Research, Vol. 18 (19), p. 1-16.

Sunderland, N., Catalano, T., Kendall, E. (2009). Missing Discourses: Concepts of Joy and Happiness in Disability. Disability \& Society, Vol. 24 (6), 703-14.

Tashakkori, A., Teddlie, C. (2003). The Handbook of Mixed Methods in the Social and Behavioral Research. Thousand Oaks, CA: Sage.

United Nations Convention on the Rights of Persons with Disabilities. (2006). Convention on the Rights of Persons with Disabilities. http://www.un.org/disabilities/documents/convention/convoptprot-e.pdf [Accessed 04-01-2017].

Vehmas, S., Watson, N. (2014). Moral Wrong, Disadvantages, and Disability: A Critique of Critical Disability Studies. Disability and Society, Vol. 29 (4), p. 638-650. 
